\title{
Resource Superiority of University-enterprise Cooperation of Investment-oriented Enterprises
}

\author{
Xiaoli Dang \\ College of accounting, Xijing University, Xi'an, 710123, China \\ hunter2011@foxmail.com
}

Keywords: University-enterprise cooperation, Present situation investigation, Investment-oriented enterprise resource

\begin{abstract}
Based on analyzing some problems existing in university-enterprise cooperation process, this paper discusses university-enterprise cooperation from three aspects (university-enterprise cooperation idea, cooperation platform and cooperation system) and proposes can effectively utilize the superiority of investment-oriented enterprises to drive university-enterprise cooperation.
\end{abstract}

\section{Introduction}

As everyone knows, the university occupies a very important position in China's education field and has gradually become the original place of undergraduate education. However, since some universities have limited school-running level, low teaching level and insufficient fund supply, some universities are in the adverse position in terms of national resource acquisition. Thus, this paper discusses and studies that universities apply congenital advantages to expand their teaching level and teaching team in the new period. Universities may cooperate with local investment-oriented enterprises and improve talent training quality through such brand-new talent training mode. This brand-new teaching cooperation mode is a great practice topic of higher education development.

\section{Present situation of training talents by applying investment-oriented enterprise resources}

This paper adopts expert interview form to survey relevant universities which cooperate with investment enterprises, and utilize effective resources of investment enterprises to train talents. The following cooperation forms are found through the survey.

University-enterprise cooperation to build entrepreneurial practice base for undergraduates. Investment-oriented enterprises provide sites and equipment for universities as well as some necessary funds. Universities organize some students of relevant majors to practice on the site and create a favorable entrepreneurial environment for students through joint efforts. Neoglory undergraduate entrepreneurial practice based jointly built by Zhejiang University of Technology and local Neoglory Holding Group well promotes students' business startup. This base is jointly contributed by the university and Neoglory Holding Group. Neoglory Holding Group provides excellent entrepreneurship teachers and high-tech products of the company as well as certain technical support for the university. The university arranges rational time and practice post to meet students' demand. Through such education form, the universality not just trains talents with development potential, but also improves students' practical ability. Zhejiang Normal University and Beijing Tsingtoo cooperate to build innovation base in the campus to provide favorable entrepreneurial environment and to cultivate a group of talents with spirit of innovation. Hangzhou Dianzi University and Hangzhou Economic and Technological Development Zone cooperate to set up scientific innovation and industry incubation base for undergraduates in Hangzhou and create a good platform for students' business startup.

Universities employ the personnel of investment-oriented enterprises as entrepreneurship tutors. Universities employ excellent investment entrepreneurs and senior management experts to serve as entrepreneurship tutors who guide students' business startup. If successful people teach students, students can profoundly experience hardships and successful experience in the 
entrepreneurial process. In recent years, these investment enterprise personnel have become an important constituent part of entrepreneurship teaching team in universities. Wenzhou University employed founders of some excellent enterprises such as Red Dragonfly Group and Aokang Group to carry out entrepreneurial lecture, to narrate some problems in entrepreneurial process, to evaluate entrepreneurial skills and to guide students about laws and regulations in entrepreneurial process. The involvement of these successful people can effectively make up for shortcomings in entrepreneurial practice.

\section{Problems of training talents by depending on investment-oriented enterprise resources}

Through investigating these universities, it is found that these universities strive to survive during development and they are actively blending in local economic society. These universities actively operate with investment-oriented enterprises. The sponsorship of these companies for universities effectively drives teachers' ability and teaching level, and relieves shortcomings of students in entrepreneurship field to some extent. Meanwhile, we also find the cooperation between universities and enterprises is not perfect, and some obvious problems exist in cooperation between investment-oriented enterprises and universities. For instance, the cooperation between universities and enterprises is not thorough, and the bond between universities and enterprises is not firm. The survey in recent years shows university-enterprise cooperation level is relatively low. Some activities are just superficial, and fail to really reflect significance of university-enterprise cooperation. In addition, coordination mechanism of university-enterprise cooperation still needs improvement. These factors hinder development of university-enterprise cooperation. We believe university-enterprise cooperation will achieve greater results in China's education field through efforts.

University-enterprise cooperation fails to effectively fuse with students' entrepreneurial practice. Through university-enterprise cooperation, universities will generate certain amount of transverse scientific research projects annually, and large quantities of achievements in scientific researches will appear in these projects. However, certain dormancy period will occur after these achievements come out. Besides, in students' entrepreneurial practice, independent entrepreneurs have no great correlation with their specialty and even have no relation with their specialty due to the lack of market prospect and technological content. Thus, students wrong consider specialized knowledge they learn has no any help to their business startup. Through deep investigation, it is found that the reason for this phenomenon is that current undergraduates lack experience in transforming academic capital to venture capital. In this way, educational function of undergraduates' scientific and technological activities is not really exerted.

Overall level of cooperation between universities and investment-oriented enterprises is low. We also have found in the survey process that few investment-oriented enterprises can really drive university-enterprise cooperation. Most enterprises focus on company benefit, and university-enterprise cooperation is purely reflected in entrepreneurship guidance for undergraduates and sponsorship of funds and equipment. For example, university-enterprise cooperation agreement explicitly stipulates that investment-oriented enterprises should provide entrepreneurial practice base for students, and offer entrepreneurial guidance and technical knowledge for students. However, since current university-enterprise cooperation is short of operability and effectiveness, entrepreneurial practice base cannot give full play to its functions and appears in the form of an empty shell among students.

Organization and empty-shell of university-enterprise cooperation is imperfect. We also have discovered in the survey process that most universities have no special setup of organization for university-enterprise cooperation. This task is mainly handled by teaching management department. This will cause investment enterprises and government lack communication and interaction in talent training. The resources of government and investment enterprises cannot be fully utilized in universities. Moreover, among these universities, scientific research and teaching are mutually independent and own their respective management systems. Thus, functions and personnel of scientific research and teaching cross little, and the personnel lack communication. We find that 
university-enterprise cooperation is mostly embodied in scientific research management department of a university, so students lose the opportunity and it is hard to fuse university-enterprise cooperation with undergraduates' university-enterprise cooperation.

Incentive mechanism of talent training is imperfect. It is found through survey that in teachers' performance assessment, assessment objects mainly concentrate on teachers' scientific research and papers, but universities do little in the aspect of contacting investment enterprises and striving for resources. This is mainly because there is no perfect management system. It is hard for teachers to calculate the performance of investment enterprises. Existing policies of universities fail to combine with university-enterprise cooperation.

\section{Strategies of talent training by depending on investment-oriented enterprise resources}

Establish the idea of university-enterprise cooperation. In current era of knowledge economy, undergraduates should not only consider knowledge, but also pay attention to applying research achievements in practice and creating certain economic value in order to innovate for scientific research. Undergraduates may apply achievements in scientific research in society so as to reflect their real values. This is also an important approach to transform knowledge to economy. Therefore, it is required to perfectly combine university-enterprise cooperation with undergraduates' entrepreneurial practice so that students can apply specialized knowledge to provide impetus for business startup and extract entrepreneurship projects in scientific research and achievement transformation. Besides, related departments of universities should think seriously about how to boost undergraduates' innovation ability through academic capital.

Firstly, universities should rationally combine with enterprises, form a set of scientific system suitable for local industry and lay a solid foundation for development of university-enterprise cooperation. In the cooperation process, universities should run the universities in strict accordance with local requirements, accurately master outstanding field of local economic development, input scientific research in local production, grasp subject direction and form a set of complete scientific organizations locally. In addition, university subject construction should overall cooperate with local investment enterprises, pay attention to economic development dynamics anytime and cultivate professional scientific research talents suitable for local economic development.

Secondly, universities should stick to scientific concept of talent training and university-enterprise cooperation. Besides, university-enterprise cooperation should focus on development of local leading industry. The purpose of university-enterprise cooperation is not to transfer talent training to investment enterprises, but to let students really put themselves in scientific construction, research and development of high-tech products through investment enterprises, and to train students' practical ability. Thus, universities should change existing thought, actively cooperate with local enterprises, stimulate students' innovation spirit and make technical contributions in social service so as to gain technical support from the society. Universities should encourage students to transform existing scientific research innovation in practical activity, gradually transform scientific research resources to university-enterprise cooperation resources and achieve resource transformation and interaction.

Perfect university-enterprise cooperation system. Establish thorough university-enterprise cooperation management system. First of all, some departments in charge of education should establish effective leadership system and management system in university-enterprise cooperation and set up special technical support and fund support for university-enterprise cooperation. Furthermore, special university-enterprise cooperation management organization should be set up in universities. For instance, university-enterprise cooperation committee may be set up in the university to manage university-enterprise cooperation, continuously enhance the relationship with superior management department in working process, strengthen teaching and scientific research work, change original teaching idea, break through the barriers in talent training and scientific construction, cultivate innovation talents by utilization of existing resources and drive university-enterprise cooperation. 
Organize and encourage students to take active part in activities held by university-enterprise cooperation. Universities should establish innovation credit to encourage students' innovation spirit, set up innovation fund, provide students with strong logistic support, guide students to participate in logistic support and encourage students to take an active part in scientific entrepreneurial activity. Meanwhile, scientific research laboratory and engineering center should be established to offer favorable preferential policy and a superior innovation environment for students. As well, universities should establish quality evaluation system for university-enterprise cooperation and off-campus activities. Universities evaluate and organize achievements in scientific research, select some scientific and technological achievements suitable for student entrepreneurship, create entrepreneurship resource library for students and arrange professional teachers to carry out technical guidance of students' entrepreneurship. At the same time, students should know relevant rules and regulations in entrepreneurial process and specify relevant rules and regulations.

\section{References}

[1] Y.M. Wang, H.M. Zhao, D.S. Yang, A New Way for Talent Training Based on Government and University-Enterprise Cooperation. Colelcted papers of 2003 Academic Annual Conference of Electronic Society for Higher Education . 2003

[2] D. Jiang, Exploration of University-Enterprise Cooperation Mode in Chinese Higher Education [A]. Colelcted papers of 2007 Annual Conference of Chinese Pedagogical Economics. 2007

[3] J.B. Xu, D.C. Wang, X. Yu, College Innovation Education under University-Enterprise Cooperation Mode. Scientific Research of Higher education 2006 (the first volume: President Forum · Educational Reform . 2006 